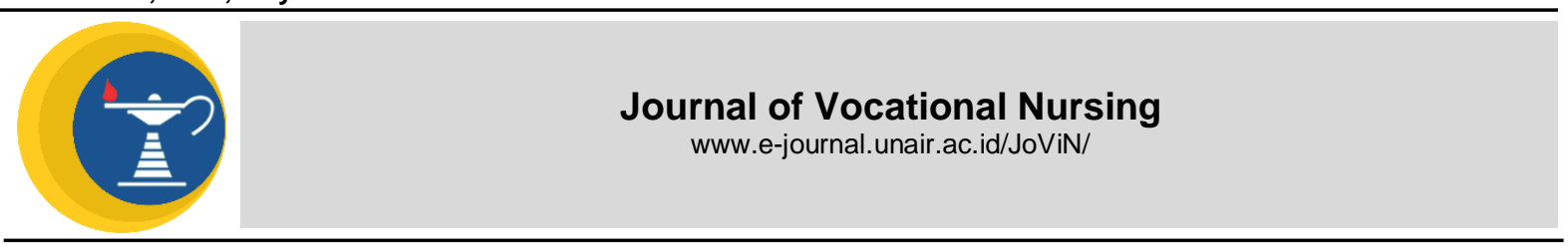

\section{THE PHENOMENON OF DIMLY LIT STALLS ALONG THE NORTH COAST ROAD (CASE STUDY OF INDIRECT FEMALE SEX WORKERS) AGAINST THE SPREAD OF SEXUALLY TRANSMITTED DISEASES IN JENU SUBDISTRICT TUBAN}

Research Report

\author{
Aris Puji Utami, Hanim Nur Faizah, Moh. Wafi Mubarok \\ Institut IImu Kesehatan Nahdatul Ulama Tuban
}

\section{A B STRACT}

Introduction: Cases of STIs continue to soar, one of which is due to the practice of prostitution because women sex workers (WPS) are one of the high risk groups of contracting and transmitting STIs. The purpose of this study was to explore knowledge and explore the behaviour of women sex workers indirectly. Methods: The design of this research uses descriptive qualitative research method with phenomonology. The subject of this study was women indirect sex workers who sold sexual services in exchange for money located in the village stalls of Sugiwaras District Jenu Tuban District a number of five women sex workers. Data collection techniques used in this research are observation and structured interview techniques. Result: The results of this study showed that participants' knowledge of reproductive health was not good, as evidenced by the women sex workers were not immediately able to explain the definition, signs and symptoms and how to prevent the spread of sexually transmitted infections (STIs). In terms of applying behaviour, participants were classified as negative because all participants revealed to have had unless condomless sexual intercourse and economic difficulties. Conclution: The sexual behaviour of female sex workers indirectly in the stalls along the pantura was classified as negative because all participants revealed to have had sexual intercourse without condoms and economic difficulties. Female sex workers also have low knowledge of STI.
ARTICLE INFO

Received April 14, 2021

Accepted May 25, 2021

Online May 31, 2021

*Correspondence:

Aris Puji Utami

*Email:

arispuji@stikesnu.com

Keywords:

Knowledge, Women sex workers, Behavior

\section{INTRODUCTION}

Nowadays, the level of morality of the Indonesian nation is getting worse, this is proven by the high number of commercial sex workers, as a result of which more and more sexually transmitted diseases are found. Commercial sex workers are divided into male sex workers and female sex workers. Sex workers work in a variety of forms. They can work localized under direct sex workers or they can also be indirect sex workers. Women Indirect sex workers get clients off the street or when working in entertainment venues such as nightclubs, massage parlors, discos, cafes, karaoke venues or bars-Some of them are WPS who have already worked localized but out of localization then work into indirect WPS in entertainment venues that they consider to have a higher class. There are also those who feel more flexible by working as Indirect WPS because it is not strictly regulated by pimps.
There is even the opportunity to earn more money when they work as coffee sellers in dimly lit stalls, karaoke guides, beer waiters, or waitresses at nightlife venues. They are known to have low rates of condom use and have higher STIs than localized sex workers.

Currently along the streets Pantura the number of dimly lit stalls is about 20 dimly lit stalls. From the data profile of disease control and environmental health in Indonesia in 2012 obtained a total of 140,803 cases of STI cases handled in 2012 from 430 STI services. According to the results of STBL 2011 there are three provinces with high rates of HIV and STS in East Java, Bali, and West Java. In Indonesia the highest number of cases of STIs in the form of abnormal (clinical) vaginal fluid 20,962 and servicitis (lab) 33,025.IMS is one of the entrances or signs of HIV (Kemenkes RI, 2013). The incidence of gonorrhea was highest in women direct sex workers (38\%), transvestites 
(29\%), homosexuals (21\%), and women indirect sex workers (19\%). Highest chlamydia incidence rate in sex worker currently along the streets Pantura the number of dimly lit stalls is about 20 dimly lit stalls. From the data profile of disease control and environmental health in Indonesia in 2012 obtained a total of 140,803 cases of STI cases handled in 2012 from 430 STI services. According to the results of STBL 2011 there are three provinces with high rates of HIV and STS in East Java, Bali, and West Java. In Indonesia the highest number of cases of STIs in the form of abnormal (clinical) vaginal fluid 20,962 and servicitis (lab) 33,025 .IMS is one of the entrances or signs of HIV (Kemenkes $\mathrm{RI}, 2013)$. The incidence of gonorrhea was highest in women direct sex workers (38\%), transvestites (29\%), homosexuals $(21 \%)$, and women indirect sex workers (19\%). Highest chlamydia incidence rate in sex worker womenmau indirect (veiled) each $41 \%$, transvestite $(28 \%)$ and homosexuals $(21 \%)$. The incidence of gonorrhea and or chlamydia ranges between 33\% homosexual and 56\% female direct sex workers. As of December 2019 , the number of AIDS cases reported was 17,394 people, and 36,881 cases of HIV. Of these $3,679(21.1 \%)$ among them died. The Health Office (Dinkes) tuban district recorded from 2000-2019 as many as 142 people with HIV / AIDS in Tuban district died.

From the results of the initial survey through interviews conducted by researchers on September 7, 2019 in Dasin Village Sugihwaras Sub-District Jenu, Tuban district obtained from several dim stalls there researchers met with WPS indirectly said many do not understand about the transmission and danger of STI disease. And if they are offered customers who are nosed they are ready as long as the nominal given is suitable according to their rates in peddling these activities. Most customers refuse to use condoms during sex on the grounds that the pleasure and passion that customers feel will decrease. These WPS also don't want to quit their jobs before they get what they want in other words rich. From the results of the initial survey through interviews conducted by researchers on September 7, 2019 in Dasin Village Sugihwaras Sub-District Jenu Tuban district obtained from several dim stalls there researchers met with WPS indirectly said many do not understand about the transmission and danger of STI disease. And if they are offered customers who are nosed they are ready as long as the nominal given is suitable according to their rates in peddling these activities. Most customers refuse to use condoms during sex on the grounds that the pleasure and passion that customers feel will decrease. These WPS also don't want to quit their jobs before they get what they want in other words rich.

Women sex workers or dim stall waiters have always been identified with female sex, although in reality nowadays men are also starting to penetrate this profession. The head of the social rehabilitation department at the Social Services office said the number of sex workers they get is only a fraction of the number of sex workers, and this number does not include workers in karaoke places who have side jobs as prostitutes. He also admitted that it is very difficult to get information about the whereabouts of other sex workers (Tuban Regency Social Service, 2008). Someone who Women sex workers or dim stall waiters have always been identified with female sex, although in reality nowadays men are also starting to penetrate this profession. The head of the social rehabilitation department at the Social Services office said the number of sex workers they get is only a fraction of the number of sex workers, and this number does not include workers in karaoke places who have side jobs as prostitutes. He also admitted that it is very difficult to get information about the whereabouts of other sex workers (Tuban Regency Social Service, 2008). Someone who Women sex workers or dim stall waiters have always been identified with female sex, although in reality nowadays men are also starting to penetrate this profession. The head of the social rehabilitation department at the Social Services office said the number of sex workers they get is only a fraction of the number of sex workers, and this number does not include workers in karaoke places who have side jobs as prostitutes. He also admitted that it is very difficult to get information about the whereabouts of other sex workers (Tuban Regency Social Service, 2008). Someone who decidesDim stalls or women sex workers are not actually their main goal in life, but rather as one of the efforts to achieve other more important goals, because they never aspire to undergo the profession as sex offenders and want to live their profession due to various factors. These factors include economy, broken heart, marital status, debt, education and offspring.

The issue of prostitution is a complex problem because it is related to the order of values, religious norms and culture of society. There are several factors that cause a woman to become a Commercial Sex Worker, among others: economic factors, low levels of education, income who can't better meet daily needs and problems in the family (Munawaroh, 2010). From the explanation above, it can be 
concluded that many factors cause women to fall into the world of prostitution. The most powerful factor is the economic factor. Women tend to want to live luxuriously and adequately, but are also lazy to work, then choose a job to be a dimly lit stall maid or a female sex worker.

From these problems, efforts are made to rehabilitate dimly lit stall maids or women sex workers to make their consciousness intact with the dangers of working into more sex offenders, it would be good to include them in community and religious organizations, as well as those closest to giving full affection to strengthen and transform into better personalities than ever before.

Based on this background, it is the reason for the study of the phenomenon of dimly lit stalls along Pantura road (case study of women indirect sex workers) in Jenu Subdistrict, Tuban Regency.

\section{MATERIALS AND METHODS}

In this study using qualitative phenomenology research method, which is a research method based on the philosophy of post-positivism, used to examine the condition of natural objects (as opposed to experiments), where researchers are as a key instrument, data collection techniques are carried out in triangulation (combined), data analysis is inductive or qualitative and qualitative research results emphasize meaning rather than generalization (Sugiyono, 2015).

\section{RESULT}

\section{General Data}

1. Overview of research places

1) Research Location

District Jenu is a district located on the Pantura line, precisely $10 \mathrm{~km}$ west of the city of Tuban with an area of $81.61 \mathrm{~km}^{2}$ with a border area, in the north there is the Java Sea, the east there is Tuban District, the south there is Merakurak District, and the west there is Tambakboyo District.Jenu sub-district carries 17 villages, one of which is Sugihwaras Village. The location of this research is located in a dimly lit dimly lit stall located on JI. R.E Martadinata with a house in front of it in the form of a stall with orange walls. When viewed from the front like a coffee shop usually, but at the back of the stall there is a room with a white plywood board door and there are light red curtains that provide a brothel that is used to fulfill the passions of customers. And two other stalls located next to Jl. Raya kragan-rembang with bamboo woven stalls with white chat or commonly called gedek by east Java people, by providing coffee drinks and there are also alcoholic drinks for customers, with there is a female seller who dresses sexy to offer sex where depending on the customer, if the customer does not provide a place to rent a room next to the stall by paying 50,000 thousand rupiah per hour

2) Participant Characteristics

Participants in the study were five female sex workers, aged between 27 and 32 . Participants are generally divorced and one participant is unmarried. The religion embraced by all participants is Islam. Most of the participants had side jobs, in addition to colonizing sex as well as being the custodians of coffee shops on the sea side of Pantura Tuban at night.

Participant 1 This participant was a woman aged 27 years and she was married but ended up or divorced by having 1 child fostered by the mother of the participant, she adhered to islam and native javanese tribe. Currently, participants are located in one of the boarding houses not far from where they work in a stall on the edge of Jl. Kragan Rembang-Surabaya which was originally his house outside Tuban regency. Participatory started his work as a waiter of this stall for almost 2 years. Has TB $150 \mathrm{~cm}$ and $\mathrm{BB} 66 \mathrm{~kg}$ with round face and blond hair make the nosed male attracted to the participants, and in addition to the way of dressing open and slightly show the prominent parts are very able to attract the sexuality of men.

a.Participants answered questions casually by ingering on chairs and willing to answer if they were paid the wages of the researches. Participants worked as stall waiters no longer because of economic needs and for their children's school fees. Participants 2 Participants were female with moles under the nose, aged 30 years and had been widowed for 6.5 years, had 1 child in the care of her exhusband, islamic religion and native Javanese tribe. The place to stay and the stalls he worked with the first participants. Participants have a unique way to invite men to come to the stalls and have sex by using the app in smartphone. How to dress in sexy clothes. Having a slightly fat body and yellow skin was used by participants to attract sexual customers. Participants answered the question firmly in with smiles and willing to answer if there is 
a reward. Participants worked as sexual offenders due to urgent economic needs and were used for their daily needs. Participants 3 Participants were female and 29 years old. It has an Islamic religion and is native to Javanese tribes. Participants started the habit of becoming sexual workers because they used to be invited to karaoke places and have sexual intercourse after everything in the husband's residence chose another woman. Long time unable to finance his daily life participants started working as waiters in coffee shops and there were customers who offered to have sex with the paid and then became a habit of participants with being a stall maid and sex worker, having an ideal body, face dress up, dressed in short T-shirts and miniskirts became the mainstay of participants to captivate customers' lust. Participant replied casually while smoking with his squelched stance. Away from the family became the freedom of participants to work as sex workers in a stall located on Jl. R.E. being a stall maid and sex worker, having an ideal body, face dress up, dressed in short Tshirts and miniskirts became the mainstay of participants to captivate customers' lust. Participant replied casually while smoking with his squelched stance. Away from the family became the freedom of participants to work as sex workers in a stall located on JI. R.E. Martadinata4.

b. The participants were female and 32 years old, of Islamic religion and native to Javanese tribes. Having mature skin, slightly fat and round-faced body makes participants not so much in the lyrics of the customer. So that she can make money by working as a sex worker by lowering the price of onetime sex rates from 100 to 150 thousand rupiah. How to dress sexy and dress up. Participants answered the question by sleeping and relaxing while clutching. Participants became sex workers because they used to have broken home in addition to splitting up with their ex-husbands in order to do their daily needs. The place to work in the stall is the same as participant 3 Participants 5 Participants of female gender, aged 31 years, Muslims and native Javanese tribes. Original residence outside Tuban district and now live in one of the boarding houses in Tuban subdistrict. Started working at 19.00-01.00 WIB in coffee shop. Dressed in tight jeans, a short T-shirt, face dress up and long black hair tied back. Participants answered casually by smoking cigarettes and were not nervous to answer questions that were on a chair in a stall located on Jl. R.E Martadinata

\section{Additional data}

1. In this study produced two specific objectives, namely digging into the reproductive health knowledge of women sex workers indirectly dimly along the road Pantura District Jenu Tuban regency and dig deeply the sex behavior of women sex workers indirectly in dim stalls along the road Pantura District Jenu Tuban Regency. The results of the study were described based on participants' answers to interview questions and field defects during the data retrieval process. Women sex workers' indirect knowledge of reproductive health.

1)13 participants $(60 \%)$ revealed that a good sexual relationship / ideal is a sexual relationship by keeping the body from contracting HIV by using condoms, following the quote "Tergantung pelanggane mas, nek njaluk seng apik yo gawe kondom (depending on the customer sir, if ask for good service, we wear condoms)", and 2 participants (40\%) not concerned about the health of his body, "Walah... gak mudeng aku mas (I don't understand sir)". All participants $(100 \%)$ states wearing condoms prevent the transmission of sexually transmitted infections one of them by using condoms following the quote: "yo pakek kondom, selanjute iso di bersihno bar main (yes, use condoms, continue to be cleaned after sex)". "Nggawe kondom, nek kenek, budalo na dokter mas (wearing condoms, if infected, checked to the doctor)". Most participants (80\%) in maintaining reproductive health is to offer condoms to customers who want to have sex, era there are also those who take drugs to keep their body healthy and quote: " Aman ya pakai kondom, lebih aman nek ono duite mas (safe to use condoms, and safer if there is money sir)" "Nggawe kondom cocok gawe bermain (Using condoms during sex)" "Ngombe mas mben obat sehat terus berlanjut (take drugs sir, let healthy continue)" While the efforts carried out 
to prevent STIs 4 participants $(80 \%)$ offer condoms to customers and if they refuse to be served because they want satisfaction by not using condoms and for their daily needs to survive, here's an excerpt: "Yo, biasane wong-wong tako kon gawe kondom wae mas, tapi piye maneh akeh seng njaluk gak gawe kondom (yes usually I ask customers to use condoms, but most of them won't to use condoms)" "Podo wae mas, jarene penak ra gawe kondom (all the same, he said it's good not to use condoms)" "Podo mas, aku sek butuh manganese sek pengen urip ( same sir, I still need to eat and want to live)" While (20\%) taking drugs to prevent STIs, here's a quote: "Yo kui, ngombe obat pot koyo amoxilin, supertetra kan murah, la na rumah sakit lak larang (yes, take medicine from pharmacies like amoxillin, supertetra because cheap, if in the hospital is expensive)" Most participants said that the signs and symptoms of STIs are thin-bodied following the quote: "nek wong-wong takok yo e awake kuru, kulite ireng awake gak ndue doyo (if people say his body is thin, his skin is black and his body is limp)" "awake kuru, iku tok ngertiku mas (skinny body is all I know sir)" The behaviour of women sex workers indirectly in dim stalls Asn large participants revealed to have done any form of sexual intercourse or sexual behaviour during being a female sex worker indirectly and the reason for doing such behaviour is to earn money, here is the excerpt: "Wes khatam mas, tapi biasane akeh wong seng njaluk ngene seng njaluk ngnu aku yo emoh, pegel e jayah" (I understand everything sir, but usually many people who want to ask for this way ask so I do not want, his aches for mercy)" "Ora reno-reno mas (no Weird)" Most participants revealed that the reason for doing such behaviour is his work to make money in every sexual relationship, here's a quote: "Golek duwit mas, jagane mangan sesok (find money sir, to eat tomorrow)" "Jenenge ae purel mas, yo gawene isone kui, nek gak dibayar emoh lah (his name wrote women sex workers, yes his work can be so, if not paid so Ido not want)" Almost all participants revealed that they still serve customers who refuse to wear condoms by prioritizing the money earned from sexual intercourse, especially those who are tied to contracts that have been paid, following the quote "Yo nek gak ya piye, penting dibayar (yes if you do not want it's okay, the most important in paying)". "Nek aku biasane rodok kasar sitik mas, ya kamu tahu, aku ya butuh duwite iku mau, ha tetep gak ditayangno, tapi nek keno HIV ngunuku yo sakno keluargaku mas (if I'm a little hard sir, yes you know, I also need the money, I still serve, but if anything happens let alone contracted HIV pity my family sir)". Most of the participants said that every day they replaced their spouses with money, and some said that. use security if customers want to use the following quote "Nek gak gonta-ganti lak gak entuk uang (if it doesn't keep changing, i can't get the money)" "Gonta ganti maneh mas, Yo wes salah sijine yo nganggo pengaman iku wae ben gak tuli, nek gelem tapi" (change again sir. yes, one of them is using security so you don't get infected, but if he wants). All participants stated that wearing condoms prevented the transmission of sexually transmitted infections, wearing condoms.

\section{DISCUSSION}

Women Sex Workers' knowledge indirectly about reproductive health Based on the results of interviews with women sex workers indirectly that $60 \%$ of participants knew good sexual relations or ideal, all participants knew the prevention of STIs, $80 \%$ of participants maintained their reproductive health, $80 \%$ of participants were able to strive to avoid STIs, and almost all participants were able to explain the signs and symptoms of sexually transmitted infections. And every customer is offered condoms by female sex workers, but knowledge of how to prevent sexually transmitted infections using condoms is still minimal for both women sex workers and their customers. Participants' knowledge of sexuality was built on their ability to think about what they knew, they saw, Women Sex Workers' knowledge indirectly about reproductive health Based on the results of interviews with women sex workers indirectly that $60 \%$ of participants knew good sexual relations or ideal, all participants knew the prevention of STIs, $80 \%$ of participants maintained their reproductive health, $80 \%$ of participants were able to strive to avoid STIs, and almost all participants were able to explain the signs and symptoms of sexually transmitted infections. And every customer is offered 
condoms by female sex workers, but knowledge of how to prevent sexually transmitted infections using condoms is still minimal for both women sex workers and their customers. Participants' knowledge of sexuality was built on their ability to think about what they knew, what they saw, what they experienced, and what they found around them. In accordance with what Notoatmodjo (2010) said, knowledge occurs because of an act of sensing a particular object in the form of vision, smell, hearing, taste and taste that causes one to know. In knowledge has 6 stages or levels in the cognitive domain namely: know (know), Understanding (comprehension), Application (application), Analysis (analysis), Synthesis (synthesis), Evaluation (evaluation) (Notoatmodjo, 2007). Acquired Immunodeficiency Syndrome (AIDS) is caused by Human Immunodeficiency Virus (HIV) which causes weakening of a person's immune system, makes him more susceptible to various diseases, difficult to recover from various opportunistic infectious diseases and can cause death (RISKESDAS, 2010).

Based on the results of research interviews and the theory above that most of the participants knew about a good or ideal sexual relationship, participants who knew about STI disease obtained the information from the internet and from print media. Almost all participants were able to answer and explain how to prevent STIs, participants who were not able to answer more because of their knowledge. Most participatory are able to maintain the health of their production by marrying condoms every time they have sexual intercourse. Most of the participants were also able to try to avoid STI. Most of the participants were able to mention signs and symptoms of STIs such as skinny body, smelly genitals, while participants who did not know only gave answers to thin bodies. The results of the study agreed with philepmorseregar with the research of commercial sex workers' knowledge by preventing venereal diseases by showing enough knowledge of participants about venereal diseases so that the attitudes obtained about venereal diseases are also good. Cannot get an optimal attitude because knowledge is only enough. Most of them do not yet know that venereal disease is very dangerous and should be avoided and prevented. Awareness of prostitutes is also low, the exhortation about the use of condoms is still often ignored when one of the prevention is to wear condoms every time they have sex. Because STIs are one of the reproductive tract infections (ISR) that are transmitted through intercourse. Germs that cause such infections can be fungi, viruses and parasites (Widyastuti \& Rahmawati, 2009). WPS's knowledge of venereal disease is one of the factors that influence WPS's attitude about venereal diseases. Because with existing knowledge can influence the attitude of WPS in understanding about STIs that can be done daily. Therefore, it is expected that health workers or cadres are expected to always provide conseling or conseling to prostitutes. Because complete and precise information gradually Women Sex Workers' can know and receive information about venereal diseases and can apply it well. This is where the incidence of venereal disease can be minimized. Inferred that women's knowledge of sex workers was indirectly good enough, participants were able to maintain reproductive health but participants were reluctant to take such precautions or use condoms during sexual intercourse on the grounds that economic demands had an impact on negative behaviour in women sex workers, which had a high risk of transmission of sexually transmitted infectious diseases. Female Sex Workers' behaviour indirectly in dimly lit stalls Based on the results of the researchers' interviews by deeply digging into the behaviour of women sex workers in dimly lit stalls that all participants expressed fear if exposed to STIs, therefore they offered condoms in sexual intercourse even though customers refused to use this condom safety device. Of the 5 participants on average they became female sex workers already 2 years. All participants said having sexual intercourse was used to work in order to earn money for the expenses of themselves or their children in daily life due to low economy. Most participants did not make a refusal attempt if the customer refused to use condoms. Most of the participants every day if there are customers must be served even with a change of partner. Most offer condoms to customers and are still served if customers don't want to use them. Some of the reasons customers do not want to use condoms are customers feel bad or uncomfortable, less satisfied, and not a few of the customers feel themselves healthy so there is no need to use condoms in sex with WPS (Kenderwis \& Yustina, 2010). According to Koentjoro (2004) the term female sex worker is a new term that contains the same meaning as commercial sex workers, morally impaired women and prostitutes. The term female sex worker is often used by experts, practitioners, health services, female activists and HIV/AIDS to change the term whore, in consideration of this term feels more subtle and seems not to corner their work as prostitutes. Lawrence Green mentioned that the factors that influence behaviour are predisposing factors namely 
knowledge, supporting factors, driving factors, as well as environmental factors namely poverty, free sex, derivatives and broken home. Based on the results of research interviews and theories above, it can be concluded that all participants expressed fear of death from STIs, because their work at high risk of transmission of venereal disease and HIV/AIDS was added to still having sexual intercourse by not using condoms, participants who expressed fear of knowing most about the causes, signs and symptom and ways of transmission of HIV / AIDS. The average participant has been a sex worker woman for 2 years with a background of economic factors and failed marriage status that makes participants choose this kind of work, in addition to the history of education in participants who are mostly junior high school educated makes participants have no alternative jobs that can be done, related to the level of awareness and knowledge about the risk of diseases that can be contracted from customers. Almost all participants knew that condoms could prevent the occurrence of STIs, but the awareness of customers to wear condoms was very low, making almost all participants continue to serve customers who do not want to wear condoms. All participants did not believe that their customers were not affected by STIs, participants tended to give up and serve all customers regardless of the possibility of transmission of STIs.

\section{REFERENCESS}

Kemenkes RI. (2013). Situasi Umum HIV/AIDS dan Tes HIV. Infodatin.

Kenderwis, \& Yustina, I. (2010). The Bargaining Power Of Commercial Sex Workers In Using Condom To Prevent Hiv/Aids Transmission At Langkat District, Province Of North Sumatera. Berita Kedokteran Masyarakat, 26(1), 22-28.

Koentjoro. (2004). Psikologi Keluarga: Peran Ayah Menuju Coparenting. Yogyakarta: Citra Media.

Munawaroh, S. (2010). Pekerja Seks Komersial (Psk) Di Wilayah Prambanan, Kabupaten Klaten, Jawa Tengah. Dimensia, 4(2), 6982.

Notoatmodjo. (2010). Ilmu Perilaku Kesehatan. Jakarta: Rineka Cipt.

Notoatmodjo, S. (2007). Promosi Kesehatan dan Ilmu Perilaku. Jakarta: Rineka Cipta.

RISKESDAS. (2010). Riset Kesehatan Dasar (RISKESDAS). Kementrian Kesehatan RI.

Sugiyono. (2015). Metode Penelitian Kuantitatif. Kualitatif dan R\&D. Bandung: Alfabeta.

Widyastuti, Y., \& Rahmawati, A. (2009).
Kesehatan Reproduksi. Yogyakarta:

Fitrimaya. 